\title{
Learning for transitions: a niche perspective
}

\author{
Luke Metelerkamp $^{1}, \underline{\text { Reinette Biggs }}^{2,3}$ and $\underline{\text { Scott Drimie }}^{2}$
}

\begin{abstract}
Roughly eight hundred million youth are projected to enter the African job market by 2050 . This presents both an opportunity and a challenge for urgently needed sustainability transitions on the continent, because with appropriate training and skills this youth bulge could be instrumental in driving systemic change. By training the youth in new practices and approaches, they could be central to creating new systems and African futures that are more sustainable and just. We focus on the question of where the new skills and competencies needed to underpin such transitions could come from and, in turn, how youth might access these competencies. We investigate these questions by exploring an emerging sustainability niche around organic agriculture in the South African food system. We used a network and power-mapping tool, Net-Map, to map the key knowledge resources used by successful organic farmers, as well as to understand how actor learning networks develop and disseminate new skills and competencies. We found that although a substantial volume of knowledge has been generated and sophisticated informal learning networks exist within the niche we studied, knowledge is highly fragmented. The development and transfer of knowledge is impeded by the absence of teaching capacity and poor institutional alignment at a provincial and national level. Our findings suggest that state-led extension services and formal training institutions are of little help to niche pioneers and instead contribute toward the path-dependency of the current food regime. The substantial implications of these findings underscore the need for further studies to investigate whether similar patterns hold elsewhere on the continent, and for other niches. If they do, our findings imply that addressing the sustainability challenges on the African continent will require creative approaches and new models of learning that are capable of developing and transferring the knowledge and practices emerging in sustainability niches to the $90 \%$ of youth in Africa who will not progress to formal tertiary training but will be central to driving potential sustainability transitions.
\end{abstract}

Key Words: food systems; learning; multilevel perspective; sustainability transitions; youth development

\section{INTRODUCTION}

Persistent unemployment and underemployment have become synonymous with the youth experience across most of subSaharan Africa. Currently $70 \%$ of Africans are under the age of 30 , and it is estimated that close to 800 million youth will enter the job market in this region by 2050 (Losch 2016). Of these, it is likely that less than half will have completed secondary school and no more than $10 \%$ will have completed any form of tertiary qualification (Minde et al. 2015). In South Africa, where the economy is more developed, $50 \%$ of people under the age of 34 are unemployed and of these, $60 \%$ have never been employed (Spaull 2013).

At the same time, the region faces many broader social, economic, and environmental sustainability challenges. Of particular relevance is the food system, which is associated with a wide range of environmental problems as well as social inequalities and injustices (Meadows et al. 1972, Rockström et al. 2009, Patel 2012, IPCC 2014, FAO 2016). The challenges in the food system are intricately linked to the youth question (Losch 2016), which both affects the food system and is driven by it (Folke et al. 2002, HoltGiménez and Patel 2009, Nellermann et al. 2009, Alkon and Agyeman 2011, Stuckler and Nestle 2012, FAO 2016). In some countries, the food economy accounts for as much as $80 \%$ of jobs (Tschirley et al. 2015). As a key source of diverse livelihoods (Filmer and Fox 2014), the food system provides a significant opportunity for absorbing youth in productive activities. However, the current food system is increasingly corporatized and exclusionary, and there has been widespread acknowledgement of the need to transform the food system to be more just and ecologically sustainable. As White (2012:16) puts it,

\begin{abstract}
There are real and important choices to be made, with important consequences for the coming generations. Will young men and women still have the option, and the necessary support, to engage in environmentally sound, small-scale, mixed farming, providing food and other needs for themselves, their own society and others in distant places? Or will they face only the choice to become poorly paid wage workers or contract farmers, in an endless landscape of monocrop food or fuel feedstock plantations, on land which used to belong to their parents, or to move to an uncertain existence in the informal sector of already crowded cities?
\end{abstract}

We argue that enabling a just sustainability transition within the region will require supporting youth to effect this transition, not just within agriculture but across the entire food economy, and could be a major area of livelihood creation (NPC 2013, Tschirley et al. 2015, Losch 2016). Acknowledging the interrelatedness of youth competencies and food system transitions, there has been a concerted call for increased investment and attention in youth skills development in the agrifood sector across the region (White 2012, NPC 2013, IFAD 2014, ReNAPRI 2014, Haggblade et al. 2015, Minde et al. 2015, Tschirley et al. 2015, Losch 2016, ASSAf 2017). If wellconceived and executed, this renewed investment represents a window of opportunity for mainstreaming emerging sustainability innovations into the food system in order to bring about wider systemic changes that address multiple challenges faced in the region, particularly with regards to employment, health, and the environment.

${ }^{1}$ Environmental Learning Research Centre, Rhodes University, South Africa, ${ }^{2}$ Centre for Complex Systems in Transition, Stellenbosch University, South Africa, ${ }^{3}$ Stockholm Resilience Centre, Stockholm University, Sweden 
However, the region currently faces severe limitations in terms of both formal and informal learning channels required to deliver the competencies needed for larger systemic transition of the food system. It is one thing to say that investment is needed to support youth skills development in sustainable agriculture, but on what knowledge is this training to be based, and where on the youthful continent will sufficient numbers of appropriately qualified trainers come from to train hundreds of millions of youth in new and more sustainable forms of agriculture? Competency development and dissemination is a substantial transitional bottleneck. There is an urgent need to consider how to enable the transformation of the current regional food regime in ways that meet larger social and environmental sustainability goals as well as opening up new, long-term employment and other livelihood opportunities for Africa's youth.

We report on an exploratory study aimed at understanding the competency networks underlying an emerging innovation niche in the South African food system, namely the organic agricultural sector in the Western Cape area. South Africa is one of only a few African countries with a significant domestic market for its organic produce (Barrow 2006, Institute of Natural Resources 2008) and Naidoo (2012) cites research showing the country could be the largest market for organic food in Africa. However, although South Africa has historically been one of the leading consumers of certified organic produce in Africa (Willer et al. 2008), in terms of production, South Africa is a relatively small player with only 250 certified producers (Willer and Lernoud 2015). However, South Africa's agricultural system comprises 250,000 market-orientated small-holder farmers and 2.5 million subsistence farmers, many of whom are not certified organic but farm largely in the absence of synthetic inputs (Okunlola et al. 2016). There is a growing focus on supporting small-scale farmers' access to organic markets through cooperative certification schemes. From a learning perspective, no dedicated organic qualification exists within South Africa's educational qualifications framework and no specialized extension services are available to organic farmers. The latent potential to expand organic production among a large number of small-holder farmers, combined with the absence of related learning and support services make the region a useful case study for the broader competency bottleneck in the region.

This paper is framed by the emerging body of theory around larger-scale systemic societal transitions. Based on interviews with successful farmers, we focus specifically on understanding where these farmers source the knowledge needed to operate in this niche, who the key actors are, and the structure of relationships in this niche. Although this study is limited in scope, we argue that it provides important insights regarding the types of competency networks that will need to be fostered and supported to enable emerging niches in the food system to grow to the point where they can drive larger systemic sustainability transitions. Further studies are needed to assess the extent to which similar patterns hold in other regions of the continent, and other emerging niches in the food system. However, as discussed in the conclusion of this paper, if they do hold, they have profound implications for the development of curricula and institutions that can support the learning required to support transitions toward an alternative food system that can provide livelihoods for the emerging African youth.

\section{CONCEPTUAL FRAMEWORK}

A range of theoretical frameworks exist for considering sustainability-related systemic transitions, including socialecological transformations (Folke et al. 2002, Moore et al. 2014), socio-technical transitions (Kemp et al. 1998, Geels and Schot 2007, Markard and Truffer 2008, Smith et al. 2010), and social movements (Biehl 2015, Zechener and Hansen 2015). Although this study draws on ideas from several of these frameworks, it is most closely aligned with the work on socio-technical change.

Socio-technical transition studies focus on three related approaches, namely the multilevel perspective (MLP), strategic niche management (SNM), and sustainability transition management (STM; Markard et al. 2012). These frameworks offer a systems-based approach to understanding the ways in which small pockets of innovation (niches) can disrupt and transform the mainstream trajectory of a particular dominant system (regime) in the context of wider changes taking place across a given system landscape (Geels and Schot 2007).

\section{Understanding niches}

A range of definitions exist for thinking about emergent niches. Smith et al. (2010:439) describe niches as "protective spaces for path-breaking radical alternatives," while Sharpe et al. (2016) suggest that it can also be helpful to think of niches as "pockets of the future in the present." The work of Geels (2012, Geels et al. 2014) best captures the way in which niches are considered in this paper, namely as locations of "radical innovation" (Geels et al. 2014:3) within which small networks of actors support novelties (social, ecological, or technological) on the basis of experimentation and shared visions (Geels 2012, Geels and Schot 2007). Through learning that unfolds during this process, actors develop new competencies and over time the niche grows through efforts to link different elements together (Geels et al. 2014).

Significant attention has been paid toward understanding the mechanisms of shielding, nurturing, and empowering sustainability niches (Smith et al. 2010). Embedded within the work on socio-technical transitions is a wide set of literature covering the role of individual and collective agency in transitions. Within agricultural contexts, Klerkx and Leeuwis (2008), as well as Batterink et al. (2010) and Balanzo Guzman (2016), highlight the specific importance of innovation brokers and innovation networks. This emphasizes that emerging niches within any social system need to be considered as sensitive constellations of skills and competencies in the making. The extent to which these ways of working have evolved will depend on the age, maturity, and particular character of the niche. It will also have implications for the kinds of approaches toward training; during earlier stages more flexible, open-ended approaches may be required than at later stages (Geels and Scott 2007, Rauschmayer et al. 2015).

\section{The multilevel perspective on transitions}

Initially conceptualized as a heuristic framework for the study of regional socio-technical transitions, the MLP is increasingly applied to the study of sustainability transitions (Smith et al. 2010). The MLP framework emphasizes how experimentation and innovation coalesce at a micro level into wider movements capable of shifting entrenched regimes at micro and macro levels. At the same time it considers how changes taking place within the macro landscape in which a particular regime exists, may create cracks or windows of opportunity that favor (or repel) the 
ability of a particular niche to shift the current regime. A systemic transition is considered to have occurred when a particular constellation of niche practices or technologies are fully embedded in society (Genus and Coles 2008).

Considering the application of the MLP to the highly socially unequal South African context (Bhorat and Khan 2018) of this research, Ramos-Mejía et al.'s (2018) work translating the MLP to conditions of stark inequality is particularly relevant. RamosMejía et al. (2018) argue that when considering socio-technical transitions in highly unequal contexts, transition scholars need to focus specifically on reconfiguring power imbalances. They go on to argue that, in many developing economy contexts, failing to do so can do more harm than good for the following reason: In contexts where both formal and informal institutions are contested, i.e., exhibit problems of legitimacy, and personalized, i.e., in the hands of elitist groups, promoting innovation without addressing inequality can worsen existing class divides (RamosMejía et al. 2018).

Shove and Walker (2007) provide related critique on sociotechnical transition frameworks. They argue that through the focus on large-scale systemic transitions, heuristics such as the MLP tend to focus attention on large systemic actors such as governments and big business. As a result, they run the risk of losing sight of the "ordinary arenas of everyday life" and the series of small decisions that individuals make on a day-to-day basis that give form to society (Shove and Walker 2007:770). Geels (2011) also notes that the MLP has been criticized for its bias toward a bottom-up theory of change.

Notwithstanding these critiques, we argue that the MLP is a useful framework for understanding how systemic sustainability transitions may unfold through youth skills development within the food system. The MLP has been comparatively widely applied to the field of agricultural innovation and food system transition, and the MLP's framing of niches and regimes provided a useful conceptual framework for interrogating our case study. As a guiding model for understanding food system transitions in the context of the institutional and cultural arrangements that facilitate or restrict change, the MLP also provides a bridge to other prominent framings of the food system, particularly Friedmann's (1987) formative work on food regimes. Although Friedmann's work defining food regimes through history predates the MLP, both bodies of literature define the regime as an incumbent configuration of institutions, policies, and market arrangements, and provide an opportunity for combining these ideas into a more interdisciplinary understanding of how change within the food system can be realized.

\section{Food system transitions and knowledge networks}

An extensive body of literature characterizing the current "food regime" has been written since Friedmann initially coined this term in 1987 (Friedmann 1993, Reardon et al. 2003, McMichael 2009, Holt-Giménez and Shattuck 2011, Bernstein 2016). Broadly, these texts describe the current food regime as a "Global Corporate Food Regime" (McMichael 2009:142), characterized by the large-scale commercialization of agriculture with increasingly high levels of commodity specialization, consolidated global supply chains, and widespread "supermarketization" of the retail sector (Reardon et al. 2003). This, they argue, has risen to the fore as a result of an increasingly neo-liberal geopolitical landscape, supported by cheap fossil fuels and ecological extractivisim. The tension between the prevailing food regime and a growing collection of food system niches pursuing different models of development, centered around themes of localization, food sovereignty, and agroecology have been highlighted (McMichael 2009, Holt-Giménez and Shattuck 2011).

Important to the African context of this study is McMichael's (2009) observation that, while the supermarket revolution within the current food regime has led to a proliferation of choice for wealthier consumers, it has also contributed to generating populations of slum-dwellers as rural inhabitants are pushed out of roles in small-scale agrarian economies. Increasingly, even believers in neo-liberal political development like the World Bank are admitting that corporate-led land investments in Africa are not fulfilling their promise of employment creation for local people (Deininger and Byerlee 2011, White 2012, ReNAPRI 2014). Exacerbating this, the limited availability of nonagricultural employment means that the "potential productivity benefits from large-scale mechanized farming are likely to be outweighed by undesirable social and equity effects" (Deininger and Byerlee 2011:36).

In thinking about large-scale systemic shifts, Carlsson and Stankiewicz (1991) highlight the need to consider the centrality competency diffusion in the change process. They suggest that the development and adoption of new technologies is reliant on "dynamic knowledge and competence networks" (Carlsson and Stankiewicz 1991:111) and that facilitating the flow of knowledge within these networks is as, if not more, important than the flow of regular goods and services. This emphasis on the networked nature of competence is shared by a range of pedagogical theorists (Hakkarainen et al. 2004, 2013, Moore and Westley 2011, Torre et al. 2016) including Goodyear and Carvalho (2013) who reason that,

Competence, which is one way of describing the end goal for a learning process, rarely resides in the head of a learner. Rather a person's competence is usually entangled in, and dependent on, a set of social and physical relationships - such that an expansive view of competence includes that person's ability to assemble and hold together the entities needed for the task at hand (Goodyear and Carvalho 2013:50).

Within agricultural education and extension, for example, there is growing recognition for the contribution that well-structured networks of farmers, rural industry operators, and experts can make to rural innovation (Gwandu et al. 2014, ASSAf 2017, Kelly et al. 2017).

From a multilevel perspective, we assert that the demographic shift unfolding across sub-Saharan Africa is a landscape level pressure on the current food regime and that it represents a window of opportunity within which regime level changes to the food system could be enacted. However, if a transition toward a more socially just and environmentally sustainable food system is to be realized in a timely fashion, youth will need to be inspired, capacitated, and supported to create a food system radically different to the direction in which the current one is headed. 


\section{DESIGN AND METHODOLOGY}

In this paper we aim to investigate and shed understanding on the ways in which new competency networks evolve within emerging sustainability niches, specifically within the food system. We investigated this using a case-study approach, focusing on an emerging niche in the food system, namely the localized organic agriculture sector in the Western Cape province of South Africa. We mapped and analyzed competency networks using Net-Map. Based on our analysis of these networks, we discuss how the dissemination and uptake of sustainability-orientated competencies can potentially be accelerated in agricultural training, and more broadly in education in Africa.

\section{Case study}

The South Africa food system is at an advanced stage of transition toward a globalized corporate food regime relative to other African countries. It is increasingly becoming the launch pad for corporate expansion of the agri-food sector into the rest of the continent (Metelerkamp 2014). South Africa is also a relative underperformer in terms of educational outcomes and had a youth unemployment rate of around 50\% in 2014 (Spaull 2013, NYDA 2015).

At the same time, a range of grassroots movements are emerging in the South African food system. These mainly focus on agroecological production, food sovereignty, and localization. The emerging coalition between these movements represents an increasingly coherent and structured set of actors who share a transformative vision for the food system. Collectively, these actors have piloted a set of radical alternatives to the dominant models of food production, distribution, and retail. From a multilevel perspective, this diverse coalition of farmers, retailers, community members, and others, is a textbook example of an emerging systemic niche (Geels and Scott 2007).

We focused on successful actors within this emerging food movement to gain insight into how learning for change takes place within these niches in the context of a complex systemic crisis. In order to demarcate a study boundary around a particular set of competences, we focus on the organic farming component of this network. This provided a relatively well-defined subset within the overall network of actors.

\section{Sample}

We individually interviewed a socially and economically diverse sample from formally certified as well as cooperatively certified farms. We also individually interviewed support organizations servicing this mix of farmers. A snowballing sampling process was used to develop a shortlist of 50 organic farmers in the Western Cape province of South Africa. From this short list, five farmers, each representing a different scale of operation and farm type, were selected for interviews (Table 1). This selection was based on a 5-point ranking by their peers to determine their success at the particular scale of farming as well as their relevance to the sector. The interview (using the Net-Map process, see below) was conducted on-farm and lasted between one-and-ahalf and three hours per farmer, followed by a farm tour and broader discussion with each. A similar process was followed for sector organizations of which seven were selected (Table 2). Each represented different sector elements and was interviewed for between two and three-and-half hours.
Table 1. List of farmer respondents.

\begin{tabular}{lcc}
\hline \hline Farm Type & $\begin{array}{c}\text { Years in } \\
\text { operation }\end{array}$ & Farm size \\
\hline Urban Community School & 1 & 0.1 ha \\
Garden & 2 & 0.5 ha \\
Peri-urban micro vegetable farm & 10 & 1.5 ha \\
Rural vegetable farm & 14 & 10 ha \\
Peri-urban vegetable farm & 11 & 24 ha \\
Urban vegetable farm &
\end{tabular}

Table 2. List of sector organization respondents.

\begin{tabular}{lc}
\hline \hline Organization Type & $\begin{array}{c}\text { Respondent years' } \\
\text { experience }\end{array}$ \\
\hline Retail Cooperative & 7 \\
Sector Activist & 7 \\
Sector Representational Body \& Training & 44 \\
Local Fresh Produce Market & 25 \\
Rural Development and Organic PGS & 10 \\
Provincial Department of Agriculture & 9 \\
Farmer Advocacy and Training & 40 \\
\hline
\end{tabular}

The small sample is congruent with other Net-Map studies (Johnson et al. 2009, Schiffer and Hauck 2010). Rather than aiming for broad representivity, this was an exploratory study that aimed to gain in-depth interpretative understanding based on a cross-section of pioneers in this niche environment. Denzin and Lincoln (2011:4) describe qualitative interpretative research as a process of bricolage, "a pieced together set of representations that are fitted to the specifics of a complex situation" to understand how a specific solution "takes new forms as different tools, methods, and techniques of representation and interpretation are added to the puzzle." This kind of in-depth, mixed-methods approach is recognized to be well suited to complex systemic problems (Swart et al. 2004, Teddlie and Tashakkori 2009, Flood 2010). The exploratory nature and small sample size mean, however, that further studies are required to confirm the policy implications from this study.

\section{Net-Map process}

A range of methods are available for understanding knowledge and competency networks, including social network analysis (Liebowitz 2005), knowledge mapping (Koh and Tan 2006), and focus groups (Hellström and Husted 2004). In this study we chose Net-map because of its ability to empirically map key actors and their relationships, including power differentials (Schiffer and Hauck 2010).

The Net-Map process was developed to better understand multistakeholder systems by gathering in-depth information about resource networks, goals of actors, and their power to influence system outcomes (Schiffer and Hauck 2010). Net-Map enables participants within a particular system to surface and explain the diverse and often obscure spectrum of actors who exert influence over the outcome of a particular objective or process within that system. Net-Map merges two existing methods, namely social network analysis and power-mapping. As 
Fig. 1. Example of completed farmer Net-Map.

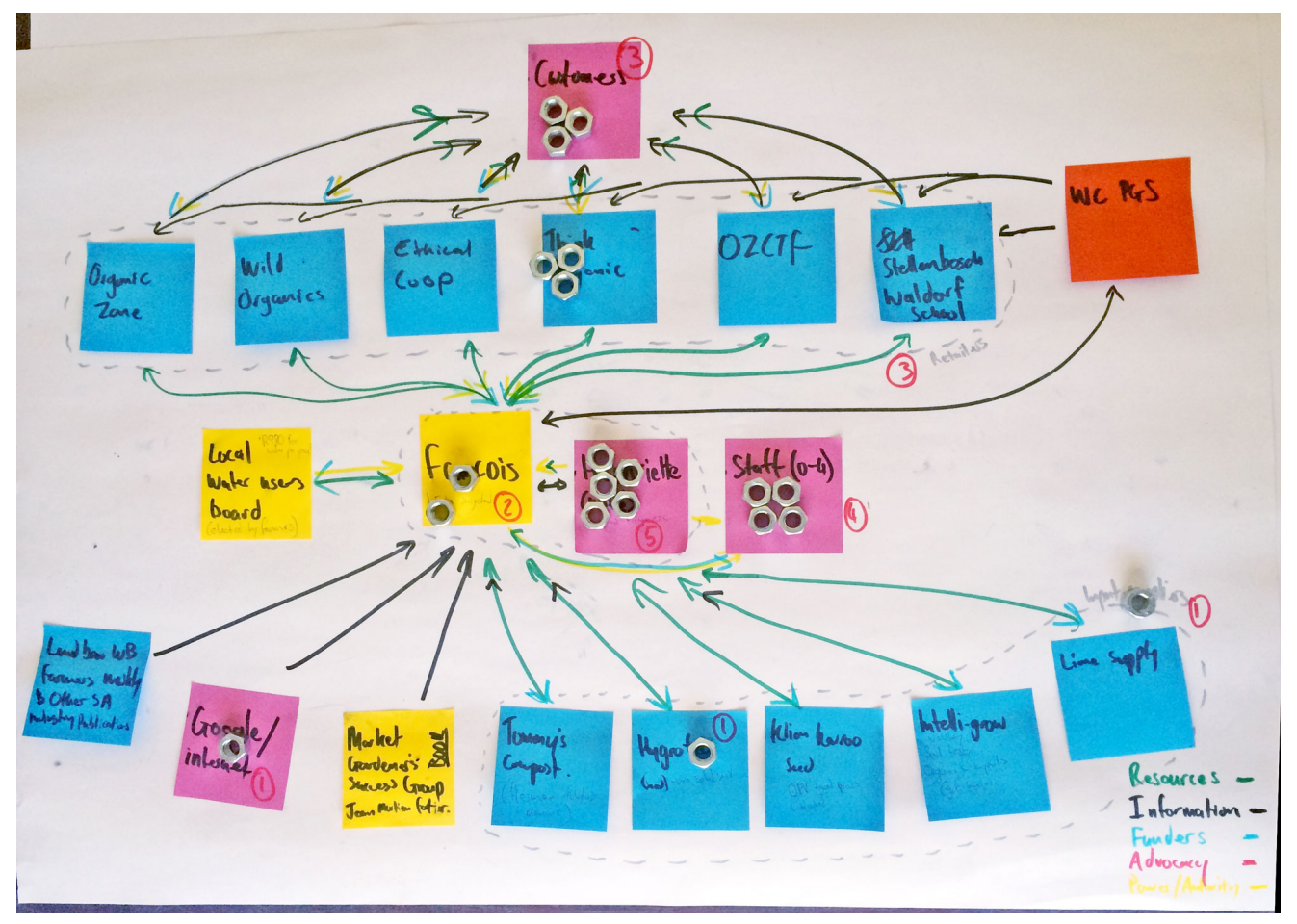

a research method, it is well suited to the collection of qualitative and quantitative information in a structured and comparable way (Schiffer and Waale 2008).

Unlike systematic literature reviews and interview analyses (e.g., using Atlas TI) undertaken in other studies into knowledge and information brokerage (Kilelu et al. 2011, Klerkx et al. 2009, Geels et al. 2014), Net-Map enables an empirical cartography of the actor networks and relationships that constitute the niche knowledge economy. These maps allow system actors to directly indicate who the relevant actors are and the ways in which they are connected to one another. A further important distinction between Net-Map and other social network analysis tools is that Net-Map allows respondents to directly overlay their perceptions of actors' power onto their own network maps (Schiffer and Waale 2008). Being explicit about actor power and positionality is particularly important in dealing "with the subtleties present in social interaction in the developing world" (Ramos-Mejía et al. 2018:222).

A clear prompting question is required to demarcate the boundaries of the Net-Mapping process for participants. The prompting question posed to interviewees was "Who are the actors that influence the success of an organic farmer in South Africa and how [/to whom] are they accountable?" This was posed to key informants on an individual basis. Working together on a large sheet of paper, interviewees and the interviewer drew up a network map of the actors whom the interviewee felt influenced the success of an organic farmer. At the discretion of the respondent, each actor was classified into one of five categories: Farmer, Community, Civil Society, State, and Private Sector.
The interviewer then guided the interviewee to establish the nature of the linkages between each of the identified actors based on a set of five predetermined types: information, finances, resources, advocacy, and authority. Respondents denoted the direction of the relationship as to/from/bidirectional. Once the actors and their links with other actors were established, the influence of these actors was established using checkers pieces to construct influence towers. This allowed the abstract concept of power and influence to be tangibly represented in a three-dimensional form. A limited number of checkers pieces were provided, so interviewees had to carefully consider who the most influential actors were. An example of the individual Net-Maps is show in Figure 1.

The 12 resulting Net-Maps ( 5 from farmers and 7 from sector organizations) were analyzed considering prevalence and influence. Prevalence refers to the frequency with which an actor or category of actors appeared. Influence refers to the weighting that the interviewees allocated to a particular actor or grouping of actors. The maps provide an initial indication as to whether there are particular concentrations of knowledge and experience in the system and which specific individuals or institutions appear to be making substantial contributions to the learning taking place within the niche.

The resulting maps and analyses were presented to an expert panel of 25 regional and international sector representatives and other farmers. Through facilitated small group engagement with the Net-Maps, this panel provided reflection on the 12 Net-Maps and the findings that emerged from the analysis. These reflections informed the interpretation of the results in this study. 
Fig. 2. Combined network map of all actors identified by farmers as sources of information that influenced their success.

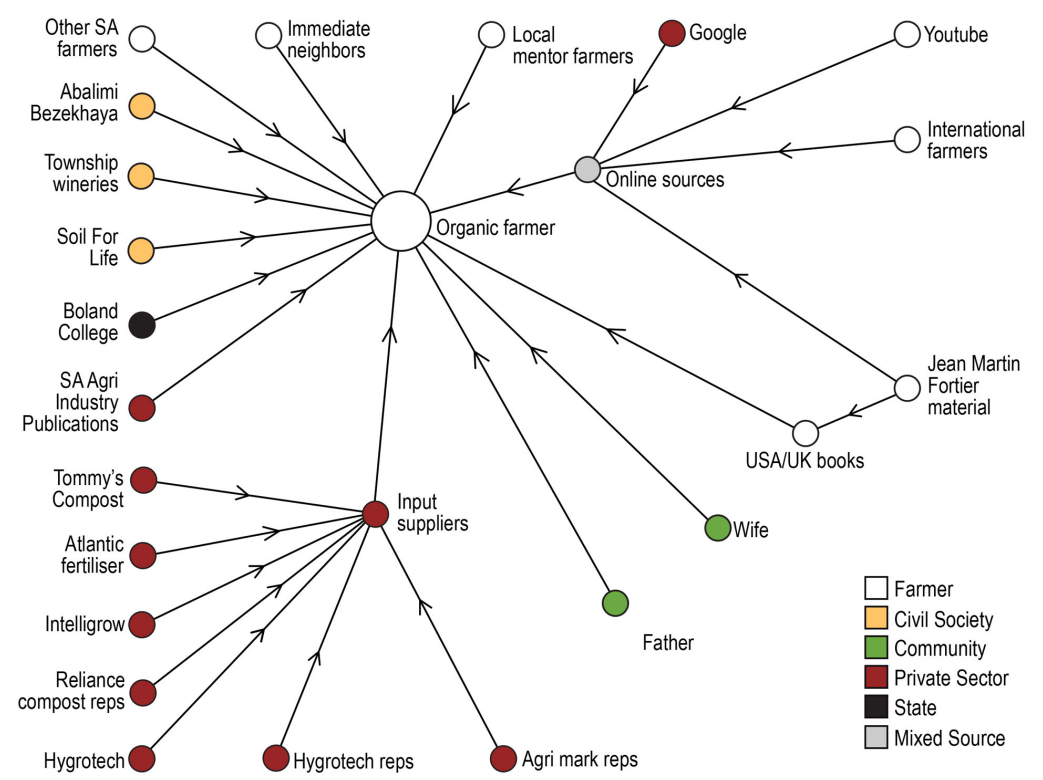

\section{RESULTS: ACTORS, INFLUENCERS, AND KNOWLEDGE NETWORKS}

The Net-Map process revealed that a substantial volume of valuable new knowledge has been generated in the organic farming niche we investigated. This ranged from knowledge about local adaptations of crop rotation practices and seed selection, all the way through the system to the development of new retail models and approaches to local community engagement.

Analysis of the Net-Maps provided insight into the range of actors engaged in the competency networks around the emerging niche organic sector in South Africa, as well as the relationships among these actors. By analyzing these networks we were able to identify the key sources and nodes of experience and knowledge that inform this competency network.

\section{Actors}

The 12 respondents listed a total of 380 actors and 880 relationships. On average, farmers listed 17 actors (ranging from 12 to 22) in their Net-Maps, while sector organizations listed 43 (ranging from 20 to 70 ). Of the 380 actors listed, 33\% were from the private sector, $19 \%$ from civil society, $16 \%$ were community actors, $16 \%$ were state actors, and $15 \%$ were farmers. Civil society largely involved nongovernmental organizations supporting farmers with training and other support services. State actors reflected the different spheres of government at local/district, provincial, and national levels, and a cross-section of different state sectors from (primarily) agriculture to rural development, water, and sanitation. Private sector actors tended to include local input suppliers, ethical retailers, and privatized information resources. Community actors included spouses, consumers, international online forums, and local families.
Importantly, respondents were not unified in their classifications of actors. For example, Farmer 5 listed the "Internet \& YouTube" as a farmer-based actor because they were using it to access others farmers' knowledge. In contrast, Farmer 3 listed it as a community-based actor because of the general spirit in which it was created and shared.

The level of connectivity and complexity depicted in individual Net-Maps also varied greatly. On the whole, farmers tended to list individuals and identify the factors influencing their success in simpler, more direct terms than sector organizations (Fig. 2). Sector organizations, for their part, considered much wider sets of relationships, extending to as many as seven intermediary actors separating farmers from those seen to be influencing their success (Fig. 3).

\section{Influencers}

Analyses of the influence and prevalence of different actors gave corresponding results. The most influential actors in the eyes of farmers were members of their community $(36 \%)$ and the private sector $(24 \%)$. These two groups of actors along with other farmers were also the most commonly listed: private sector $(42 \%)$, community $(19 \%)$ other farmers $(19 \%)$. The least influential were civil society $(16 \%)$, state actors $(11 \%)$ and other farmers $(11 \%)$. The state and civil society were also listed least frequently at $12 \%$ and $9 \%$, respectively.

The most influential actors in the eyes of sector organizations were civil society $(27 \%)$ and the private sector $(23 \%)$. These were also the most commonly listed at $28 \%$ and $24 \%$, respectively. The least influential were other farmers $(12 \%)$ and community actors $(11 \%)$. Community and other farmers were also listed least frequently at $13 \%$ and $10 \%$, respectively. 
Fig. 3. Combined network map of actors identified by sector organizations as influential information partners to farmers.

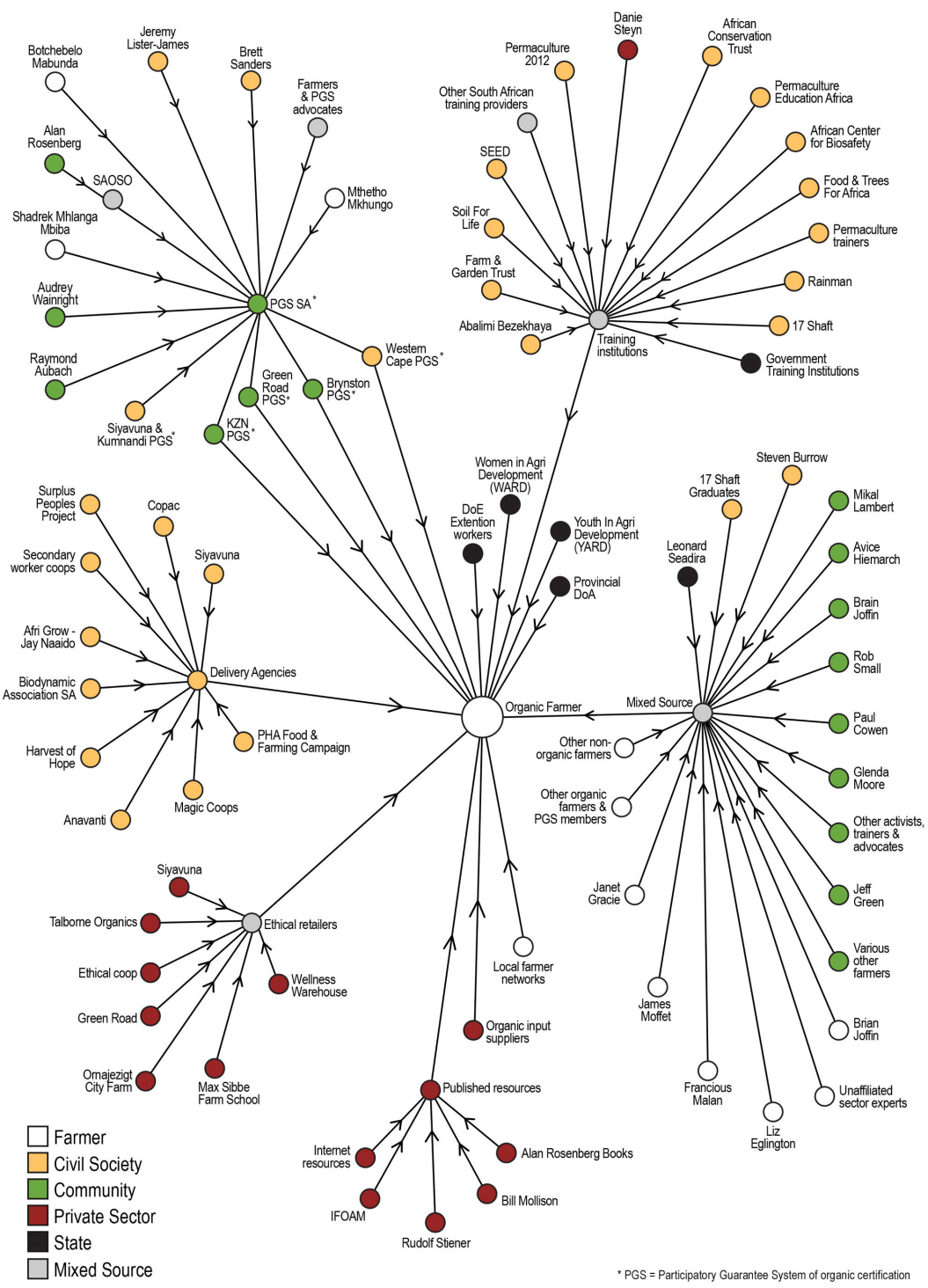

\section{Learning networks}

The Net-Maps reveal to whom farmers turn for knowledge, as well as those to whom they do not. Of the 380 listed actors, approximately $30 \%$ (124) were identified by interviewees as having knowledge or information flowing to organic farmers (Figs. 2, 3; Table 3). Comparing these 124 relationships, a number of observations can be made.

First, universities and other accredited training institutions (ATOs) are conspicuous by their absence from both farmers and sector organization networks. Farmers and sector organizations only made one reference to an accredited training institution in the direct knowledge/learning networks of organic farmers.

Second, although sector organizations recognized the private sector as an important actor overall, they did not recognize its role in the knowledge and learning networks of farmers, with only one representative of a sector organization making reference to the private sector in the knowledge network. Although representatives of sector organizations recognize the private sector, it seems they may underestimate the role that the private sector input suppliers play in farmers' knowledge networks. Similarly, they may overestimate the role that civil society plays in farmer learning.

International resources and digital learning channels featured repeatedly in farmers' views on where they sourced knowledge. Sector organizations made some reference to these and allocated no significant influence to them.

State actors seemed to have the weakest role in farmer training and knowledge networks. Where state actors like extension officers were listed, there was some sentiment that although they had an influence, this influence was not necessarily positive because they were not trained in organic agriculture. 
Table 3. Information sources as listed by farmers and sector organizations.

\begin{tabular}{|c|c|c|c|}
\hline $\begin{array}{l}\text { Farmer } \\
\text { knowledge } \\
\text { resources }\end{array}$ & Percentage & Number & Example \\
\hline Private Sector & $42 \%$ & 10 & $\begin{array}{l}\text { Hygrotech Reps, Reliance } \\
\text { Compost Reps }\end{array}$ \\
\hline Farmer & $29 \%$ & 7 & $\begin{array}{l}\text { Immediate Neighbors, Other SA } \\
\text { Farmers, Market Gardeners } \\
\text { Success Group, Google, } \\
\text { YouTube }\end{array}$ \\
\hline Civil Society & $13 \%$ & 3 & Abalimi, Soil for Life \\
\hline Community & $13 \%$ & 3 & Google, YouTube, Wife \\
\hline State & $4 \%$ & 1 & Boland College \\
\hline $\begin{array}{l}\text { Sector } \\
\text { organization } \\
\text { knowledge } \\
\text { resources }\end{array}$ & & & \\
\hline Civil society & $44 \%$ & 43 & Western Cape PGS ${ }^{\dagger}$, Abalimi, \\
\hline Private Sector & $18 \%$ & 18 & $\begin{array}{l}\text { Ethical Coop, Internet, Input } \\
\text { suppliers }\end{array}$ \\
\hline Community & $17 \%$ & 17 & Sector activists, \\
\hline Farmer & $13 \%$ & 13 & Local farmer networks, \\
\hline State & $7 \%$ & 7 & $\begin{array}{l}\text { Dept. of Agriculture, Lenoard } \\
\text { Sedira }\end{array}$ \\
\hline
\end{tabular}

\section{DISCUSSION: NEW TEACHERS AND LEARNING MODELS}

The findings from this study suggest the need for renewed attention to the role of agricultural training and development in equipping youth with the competencies required to shift and sustain new systems of food production, and foster sustainability transitions in sub-Saharan Africa. The findings surface and explain a diverse and often obscure spectrum of actors who participate in the knowledge economy of an emerging sustainability niche in the regional food system. Considered within the MLP heuristic, the insights from this study further an understanding of how learning networks among fragmented niche actors in emerging economy contexts might be better supported to enable sustainability transitions. However, our study is based on a limited sample, and additional in-depth studies are needed to establish the extent to which these findings hold in other regions of the continent and other types of niches.

\section{Key actors and knowledge brokers}

We found that the key actors in the knowledge networks underpinning the emerging organic farming niche in the Western Cape of South Africa revolved around community members, civil society, and the private sector. Markedly absent from these networks were universities and ATOs as well as state actors. The fact that more institutionalized actors are missing underscores the peripheral and niche context of the organic farming sector in the region.

Knowledge brokerage has been found to be central to innovation in agriculture (Klerkx et al. 2009, Kilelu et al. 2011, Balanzo Guzman 2016). Dutch success in agricultural innovation suggests that the best brokers emerge from the bottom up, and work at the fringes of the system outside of established research and extension services (Klerkx et al. 2009). According to Klerkx et al. (2009:435) "[a] striking feature of the Dutch case is that centrally-designed blueprints failed, and that successful innovation brokers (even if eventually subsidized) emerged in a self-organized manner, building on local, regional or sectoral initiatives, and resulting in a very diverse landscape of contextually-embedded innovation brokers." Researching farming in Columbia where rural support services are lacking, Balanzo Guzman (2016:185) notes that because "actors interested in niches struggle over scattered knowledge flow and an unstable practice base," improving knowledge flows between farmers is important.

Our data support these observations. They indicate that wellestablished, formal training institutions and extension services play a very peripheral role in the day-to-day lives and struggles of pioneer farmers in the organic farming niche in South Africa. In their absence, however, alternative "knowledge repositories" (Balanzo Guzman 2016:49) have emerged. These consisted of a rich learning network of other actors that reflect the kinds of selforganization that Klerkx et al. (2009) and Balanzo Guzman (2016) refer to. This network comprised predominantly other farmers, community actors, private companies, and civil society organizations that collaborated (often voluntarily) to support the development and dissemination of competence within the niche. Although the nature of these relationships differed according to the type of farmer, they generally comprised a blend of physical and digital learning strategies, with the latter being global in its scope.

\section{The new teachers: apprenticeship in a digital world}

In line with a growing body of international evidence on effective agricultural innovation networks (Hansen et al. 2014, ASSAf 2017, Kelly et al. 2017), information and communication technology (ICT) played an important role in the development and dissemination of competencies within the niche we researched. For example, the video tutorials and downloadable textbook based on Jean-Martin Fortier's highly successful 1.4 ha farm in Canada featured more prominently in the organic farmers' knowledge networks than all of South Africa's large agricultural universities combined.

For the farmers with good access to technology, YouTube and Google featured as common problem-solving tools for issues ranging from welding to organic pest management. Discussions with farmers during the mapping process along with analysis of the Net-Maps indicate that knowledge on a range of relevant subjects was seldom acquired through formal training. Instead, active problem solving was adopted until confronted with a challenge that the farmer could not solve alone. At this point, specific knowledge was acquired on demand. Primarily, this knowledge was sourced from other organic farmers via searchable digital channels such as YouTube and Google, or over the phone.

NGOs and private sector input suppliers also featured, but contact with these parties tended to involve personal visits. Learning through visits to other farms also emerged as a less frequent, but highly valuable, practice for two reasons. First, these visits appeared to often play a formative role in farmers' professional development. Second, because these visits were often undertaken communally with other nonfarming actors from the network (consumers, retailers, certifiers, etc.), the visits appeared 
to play an important role in developing the kinds of off-farm relationships and competencies that were critical to the development of the knowledge network.

Consequently, the knowledge network we studied reflected a blended, place-based learning approach, which is low-cost, individually customizable, project-based, and available on demand. Interestingly, many of these are features that cuttingedge tertiary institutions (Gruenewald and Smith 2014, Wiek et al. 2014, Zheng et al. 2015) and extension programs (Moschitz et al. 2015, ASSAf 2017) aspire to, but that few manage to successfully implement.

However, it was also clear from our study that some farmers were not well-networked to those "in the know," did not have the same levels of digital literacy (or access to data), did not possess sufficient awareness of knowledge resources, and did not have sufficient financial capital to engage in effective peer-to-peer learning. Farmers in these contexts cited a range of civil society organizations offering basic, mostly unaccredited, training as important contributors to their success.

\section{Formal education and extension: behind the curve}

Moschitz et al. (2015:1) have noted that while innovation and learning are key to transition, the "institutions that are charged with fostering innovation are often locked into old approaches and methods of intervention." Evidence from our data supports this view. Leading niche actors suggested that those they regarded as having the most valuable knowledge do not exist within accredited institutions or state-led extension services. We therefore conclude that despite state and donor backing, the current structures of accredited training and extension appear to be lagging behind informal (often digitized) learning networks in their ability to support the needs of agricultural pioneers in the organic food sector of South Africa.

Civil society organizations that provided training and support, such as Abalimi Bezikhaya and Soil For Life, seemed to be filling a gap for emerging farmers, which, by the Department of Agriculture's own admission, should be occupied by established training institutions and an effective state-led extension service (DoA 2017). In many instances these civil society organizations relied on the same set of individual sector specialists as betterresourced farmers. These specialists included other established farmers, input supplier representatives, and a small number of independent trainers/activists. In this sense, part of the role that civil society organizations were playing in niche learning was to act as a broker between the niche's knowledge resources and under-resourced pioneers. The important role of civil society in brokering these kinds of new knowledge partnerships has been noted elsewhere (Klerkx et al. 2009).

Where formal training occurred, it tended to be unaccredited and take the form of either practical short courses of a few days, or longer apprenticeships on existing farms. Only one of the five successful farmers had a formal qualification from an established training center. What appeared to make the short courses effective was that they had been offered as part of a holistic package of support that extended beyond training and involved the practical application of learning through the production phase and into market access. This enabled aspirant farmers to start small, providing the time and support necessary for farmers to learn experientially on their own farms. Pedagogically this can be seen as an important shift away from providing training, toward enabling "situated mutual learning" (Klerkx et al. 2011:1).

Anecdotal evidence from this study also suggests that formal training may have been trying to "start too big," offering courses that were too long, too expensive, and appeared to prepare students for entry into the mainstream agricultural system rather than the emerging niche. Typically formal training either prepared students for formal employment in the commercial agriculture sector, or for entry into their own enterprise at scales that were unrealistically large and lacked effective cohesion to the variety of supporting services required by new farmers.

\section{Pedagogical conundrum}

From a traditional training perspective, the fragmented and emergent knowledge landscape that characterizes the knowledge network in the organic farming sector niche is a challenging space to engage in. Curriculum development in the traditional sense is reliant on hindsight; tried and tested ways of doing things in a particular context, supported by reliable research, distilled into text books and lesson plans, then passed through accreditation bodies that ensure that what students are taught is correct. This in turn is taught to students by those who know how things work, operating within formal institutions that incur substantial overhead costs. This is a slow and bureaucratic process that is often expensive.

The scale of the youth challenge in Africa deepens the pedagogic conundrum. An attempt to work out how to transform the food system and then, over time, institutionalize this understanding so that it may be taught to hundreds of millions of youth across the continent would be futile given the scale and transitional nature of the challenge. This is particularly true given that the intention is not to capacitate youth for roles in the established food system regime, but rather to support them to participate in the construction of a new, and only partially defined, future.

Furthermore, current accreditation structures in South Africa, as in most of the world, tend to regard learner engagement with unsolved problems as a linear process through which students progress from learning about established knowledge at lower tertiary levels, to engaging with unsolved challenges only at a postgraduate level (Masters and PhD level; DoE 2007). In their book, Emergent Teaching: A Path of Creativity, Significance, and Transformation, Crowell and Reid-Marr (2013) describe this as a limiting approach that separates students from active engagement with real world problems and limits the potential for transformative learning within individuals and society. In the African context, projections for tertiary enrolment are below $10 \%$ and postgraduate enrolments are even lower (Spaull 2013). As a result, the current pedagogic rationale robs all but a smallest fraction of academic elites of a chance to engage in processes of real problem solving while enrolled at accredited training institutions. It also places this same elite at the head of solving problems from which they are almost completely experientially disconnected because they are typically problems of poverty.

Mainstreaming the innovations in the niche we studied thus raises both a scalar and temporal challenge. How do you teach approaches that, by virtue of their nature, have not been widely proven and lack established teachers? We argue that there is a 
need to build emergence into learning design while actively seeking out ways of working with the scattered fragments of what already exists within the niche network.

\section{Potential implications: embracing fragmented and emerging understanding}

Although our study was limited in scope, it raises a number of important potential policy implications. Because of the nature of the demographic youth bulge in South and Southern Africa, as well as the low levels of formal education among youth, our findings suggest that new models for decentralized, broad-based competency development may be needed if successful transformation of regional food systems is to be achieved. These models need to be capable of reaching the $90 \%$ of youth who will not make it to a formal training institution, and actively supporting them to build proud careers that respond to regional sustainability challenges. Furthermore, such models will need to engage learners of all levels in gritty, context-specific problem solving and take learner agency seriously. Such an approach will break with current curriculum development approaches that build on established academic knowledge. However, it also presents a risk of learners experiencing an overly daunting sense of being set adrift in the unknown.

Meeting this challenge will require effective approaches for teaching students how to develop competency within murky and fragmented niche environments. Based on our analysis and the wider literature, this should include learning how to seek out and assemble constellations of partial knowledge from a broad and dynamic network of local and global sources. The use of NetMap as a context specific anchoring device is one potential method that could be used to support the identification of relevant knowledge sources in a particular niche environment and geographical context (Metelerkamp 2019).

Our interpretation of the Net-Map data for the Western Cape organic sector implies the need to focus on methods of streetsmart knowledge acquisition and validation that prioritize personal and organizational relationships, peer-to-peer exchanges, internet-assisted problem solving, and links to carefully selected private sector input suppliers. This supports Goodyear and Carvalho's (2013) assertion that a person's competence is highly dependent on their social relationships as well as their ability to assemble and coordinate the entities needed for the task at hand. We suspect that similar patterns are likely to hold in other emerging sustainability niches, but this needs to be established by further in-depth studies.

Furthermore, a networked conceptualization of competency implies that students, and in particular those in niche environments, need to be learning about how to foster, develop, and maintain effective learning networks for their local contexts. For example, this includes knowing who to go to for what, and how to structure requests for information in ways that make it simple and rewarding for network actors to support them. These are, in many ways, highly specialized soft-skills that should not be assumed to exist. In much the same way that previously unemployed youth on a learning trajectory toward stable employment in established sectors may need coaching on how to prepare for job interviews, our study suggests that entrants into niche environments need to learn to develop effective learning networks. Similarly, if youth are expected to be adept at sourcing knowledge from unconventional sources, there is a need for those supporting youth to take into account the resources students from disadvantaged backgrounds require in order to learn how to develop effective networks, for example, weighing up whether access to mobile phone data should take priority over things such as library access.

Although we argue that it is important to focus on alternative learning models in order to support emerging sustainability niches, established training institutions clearly need to remain part of the transitional movement. In order to accelerate sustainability transitions through the incorporation of valuable niche competencies into mainstream education, mainstream institutions may benefit from seeking ways to constructively leverage the transformative potential of incomplete knowledge in niche spaces at high school and undergraduate level. At the same time, established institutions may need to improve their ability to work with the latent and fragmented practitioner knowledge that does exist. This is likely to include embracing the fact that very often those most qualified to teach about successful niche practices will never have been to university themselves and hold no formal qualifications.

\section{Limitations and future research directions}

This study was exploratory in nature and requires further corroborative work before conclusive, regional recommendations can be made.

By the very nature of selecting leading system pioneers to determine the influential actors that affect their success, the inherent soft skills with which these pioneers entered their careers were overlooked. For example, basic skills such as numeracy and literacy were largely assumed to exist among the respondents in this study. Given the low levels of functional numeracy and literacy in South Africa, this assumption may need to be interrogated in future studies. Similarly, soft skills including interpersonal skills, personal professionalism, time keeping, entrepreneurial aptitude, and self-awareness are key to success of any small enterprise. For many unemployed youth, these skills are a persistent challenge (NYDA 2015).

Additional in-depth studies are needed to establish whether similar competency networks underpin other types of emerging sustainability niches elsewhere in the region. This would help in the development of a systematic framework to guide coherent, long-term funding strategies into transformative food system niches in South and Southern Africa.

From an employment perspective it stands to reason that there are a wide range of other career options in emerging niches in the agri-food system beyond the on-farm jobs that were the focus of this study, specifically in alternative retail, organic input supply and food processing. Future work is needed to help extend this focus. Understanding these broader value chain dynamics could go a long way to increasing the number of youth able to align their personal interests and aptitudes with careers in the niche food system.

\section{CONCLUSION}

In this study we investigated the competency networks that underlie an emerging sustainability niche in South Africa, namely the organic sector in the Western Cape. By drawing on the MLP 
framework, it sought to understand how learning networks could be more effectively supported in challenging the increasingly corporatized food regimes in the region, and enable a transition toward an alternative, more sustainable food system.

Although substantial new knowledge has been generated in the niche we studied, we found that this knowledge resides in fragmented pockets that were distributed across a diverse collection of local practitioners. Niche development is hindered by low levels of systemic awareness about what is known and who holds this knowledge. Our findings suggest that a small number of key actors play a vital role in ensuring that new solutions emerging at one part of the system are connected to other parts in the system where they are needed.

We also found that beyond niche practitioners, few established teachers and experts exist. Furthermore, practitioners tend to be in the process of working out solutions themselves rather than having them at hand. Although these practitioners may aspire to teach, they appeared to have extremely limited time available to do so. Practitioner interviews as well as feedback from the expert panel both cautioned against placing additional teaching demands on niche pioneers who are often already stretched beyond sustainable capacity. This type of human resource pressure has been noted as a common transitional challenge as niches begin to mature (Moore et al. 2015) and it seems likely that the findings from this case study would be true elsewhere in the region.

The absence of established training institutions within the niche network we investigated suggests that established institutions may currently do more to perpetuate the current food regime than they do to support emerging alternatives. Given the scale of the employment and training challenges facing youth in South and Southern Africa, we see little hope for meaningful youth engagement in a sustainability transition within the food system unless valuable knowledge from pioneer networks is more effectively brought into broad-based training offerings and institutionalized curricula.

Importantly, we found that where leading food system pioneers in other parts of the world had managed to document and publish their experiences on easy-to-access platforms, this had a considerable positive impact at the local level in South Africa. This highlights the need to focus on ways of supporting African niche pioneers to record and disseminate their new knowledge quickly and effectively to a much larger audience. The region's universities could play a significant role in this process.

In summary, although a substantial volume of knowledge has been generated and sophisticated informal learning networks exist in the niche we studied, the development and transfer of competency within the niche network appears to be impeded by the absence of teaching capacity and institutional support combined with the fragmented nature of knowledge. This, in turn, hinders the niche's ability to carry hard-won lessons and solutions forward into a regime-level transition. Addressing this challenge will require creative approaches and new models of learning that are capable of effectively bridging the gaping divide between the many tiny pockets of niche knowledge and the $90 \%$ of youth in Africa who will not make it to formal tertiary training.
Responses to this article can be read online at: http://www.ecologyandsociety.org/issues/responses. php/11326

\section{Acknowledgments:}

Funding for this research was provided by the South African National Research Foundation.

\section{LITERATURE CITED}

Academy of Science South Africa (ASSAf). 2017. Revitalising agricultural education and training in South Africa. Academy of Science South Africa. Pretoria, South Africa. http://dx.doi. org/10.17159/assaf.2016/0016

Alkon, A. H., and J. Agyeman. 2011. Cultivating food justice: race, class, and sustainability. MIT Press, Cambridge, Massachusetts, USA. https://doi.org/10.7551/mitpress/8922.001.0001

Balanzo Guzman, A. 2016. Unfolding capacity: strategies of farmers' organizations as change agents. Dissertation. Universiteit Twente, Enschede, The Netherlands. [online] URL: https:// research.utwente.nl/en/publications/unfolding-capacity-strategiesof-farmers-organizations-as-change- https://doi.

org/10.3990/1.9789036541862

Barrow, S. 2006. South African organic market study. Export Promotion of Organic Products from Africa, Bennekom, The Netherlands. [online] URL: http://www.grolink.se/epopa/ Publications/Market-studies/SA\%20OMS.pdf

Batterink, M. H., E. F. M. Wubben, L. Klerkx, and S. W. F. Omta. 2010. Orchestrating innovation networks: the case of innovation brokers in the agri-food sector. Entrepreneurship and Regional Development 22(1):47-76. https://doi.org/10.1080/08985620903220512

Bernstein, H. 2016. Agrarian political economy and modern world capitalism: the contributions of food regime analysis. Journal of Peasant Studies 43(3):611-647. https://doi. org/10.1080/03066150.2015.1101456

Bhorat, H., and S. Kahn. 2018. Structural change and patterns of inequality in the South African labour market. UCT Press, Cape Town, South Africa.

Biehl, J. 2015. Bookchin's revolutionary program. ROAR Magazine 1:132-151.

Carlsson, B., and R. Stankiewicz. 1991. On the nature, function and composition of technological systems. Journal of Evolutionary Economics 1(2):93-118.

Crowell, S., and D. Reid-Marr. 2013. Emergent teaching: a path of creativity, significance, and transformation. Rowman \& Littlefield Education, Lanham, Maryland, USA.

Deininger, K., and D. Byerlee. 2011. Rising global interest in farmland: can it yield sustainable and equitable benefits? The World Bank, Washington, D.C., USA. https://doi.org/10.1596/978-0-8213-8591-3

Denzin, N. K., and Y. S. Lincoln. 2011. The Sage handbook of qualitative research. SAGE, Thousand Oaks, California, USA. 
Department of Agriculture (DoA). 2017. Farmer support and development. South African Department of Agriculture, Pretoria, South Africa.

Department of Education (DoE). 2007. The higher education qualifications framework 1997 ( Act No. 101 of 1997). Department of Education, Pretoria, South Africa.

Filmer, D., and L. Fox. 2014. Youth employment in sub-Saharan Africa. World Bank Publications, Washington, D.C., USA. https://doi.org/10.1596/978-1-4648-0107-5

Flood, R. L. 2010. The relationship of 'systems thinking' to action research. Systemic Practice and Action Research 23(4):269-284. https://doi.org/10.1007/s11213-010-9169-1

Folke, C., S. Carpenter, T. Elmqvist, L. Gunderson, C. S. Holling, and B. Walker. 2002. Resilience and sustainable development: building adaptive capacity in a world of transformations. $A M B I O$ 31(5):437-440. https://doi.org/10.1579/0044-7447-31.5.437

Food and Agriculture Organization (FAO). 2016. State of food and agriculture. FAO, Rome, Italy.

Friedmann, H. 1987. International regimes of food and agriculture since 1870. Pages 258-276 in T. Shanin, editor. Peasants and peasant societies. Blackwell, Oxford, UK.

Friedmann, H. 1993. The political economy of food: a global crisis. New Left Review 197:29.

Geels, F. W. 2011. The multi-level perspective on sustainability transitions: responses to seven criticisms. Environmental Innovation and Societal Transitions 1(1):24-40. https://doi. org/10.1016/j.eist.2011.02.002

Geels, F. W. 2012. A socio-technical analysis of low-carbon transitions: introducing the multi-level perspective into transport studies. Journal of Transport Geography 24:471-482. https://doi. org/10.1016/j.jtrangeo.2012.01.021

Geels, F. W., and J. W. Schot. 2007. Typology of sociotechnical transition pathways. Research Policy 36(3):399-417. https://doi. org/10.1016/j.respol.2007.01.003

Geels, F. W., D, Tyfield, and J. Urry. 2014. Regime resistance against low-carbon transitions: introducing politics and power into the multi-level perspective. Theory, Culture and Society 31 (5):21-40. https://doi.org/10.1177/0263276414531627

Genus, A., and A. M. Coles. 2008. Rethinking the multi-level perspective of technological transitions. Research Policy 37 (9):1436-1445. https://doi.org/10.1016/j.respol.2008.05.006

Goodyear, P., and L. Carvalho. 2013. The analysis of complex learning environments. Pages 49-63 in $\mathrm{H}$. Beetham and R. Sharpe, editors. Rethinking pedagogy for a digital age: designing for 21 st century learning. Routledge, New York, New York, USA. https:// doi.org/10.4324/9781351252805-4

Gruenewald, D. A., and G. A. Smith, editors. 2014. Place-based education in the global age: local diversity. Routledge, New York, New York, USA. https://doi.org/10.4324/9781315769844

Gwandu, T., F. Mtambanengwe, P. Mapfumo, T. Mashavave, R. Chikowo, and H. Nezomba. 2014. Factors influencing access to integrated soil fertility management information and knowledge and its uptake among smallholder farmers in Zimbabwe. Journal of Agricultural Education and Extension 20(1):79-93. https://doi. org/10.1080/1389224X.2012.757245

Haggblade, S., A. Chapoto, A. Drame-Yayé, S. L. Hendriks, S. Kabwe, I. Minde, J. Mugisha, and S. Terblanche. 2015. Motivating and preparing African youth for successful careers in agribusiness: insights from agricultural role models. Journal of Agribusiness in Developing and Emerging Economies 5(2):170-189. https://doi.org/10.1108/JADEE-01-2015-0001

Hakkarainen, K., S. Paavola, K. Kangas, and P. SeitamaaHakkarainen. 2013. Toward collaborative knowledge creation. Pages 57-73 in C. E. Hmelo-Silver, C. A. Chinn, C. Chan, and A. M. O'Donnell, editors. International handbook of collaborative learning. Routledge, New York, New York, USA. https://doi. org/10.4324/9780203837290.ch3

Hakkarainen, K. P., T. Palonen, S. Paavola, and E. Lehtinen. 2004. Communities of networked expertise: professional and educational perspectives. Emerald Group, Bingley, UK.

Hansen, J. P., M. Jespersen, L. Jensen, A. Holst, K. Mathiesen, C. Brunori, N. Halberg, and A. Rasmussen. 2014. ICT and social media as drivers of multi-actor innovation in agriculture. $C I G A R$ Proceedings 1:1.

Hellström, T., and K. Husted. 2004. Mapping knowledge and intellectual capital in academic environments: a focus group study. Journal of Intellectual Capital 5(1):165-180. https://doi. org/10.1108/4691930410512987

Holt-Giménez, E., and R. Patel. 2009. Food rebellions. UCT Press, Cape Town, South Africa.

Holt-Giménez, E., and A. Shattuck. 2011. Food crises, food regimes and food movements: rumblings of reform or tides of transformation? Journal of Peasant Studies 38(1):109-144. https:// doi.org/10.1080/03066150.2010.538578

Institute of Natural Resources. 2008. Study to develop a value chain strategy for sustainable development and growth of organic agriculture. Trade and Industry Chamber, Fund for research into industrial development, growth and equity (FRIDGE). Institute of Natural Resources, Scottsville, South Africa.

International Fund for Agricultural Development (IFAD). 2014. Youth and agriculture: key challenges and concrete solutions. IFAD, Rome, Italy.

Intergovernmental Panel on Climate Change (IPCC). 2014. Summary for policymakers. In Climate change 2014: mitigation of climate change. Contribution of Working Group III to the Fifth Assessment Report of the Intergovernmental Panel on Climate Change. O. Edenhofer, R. Pichs-Madruga, Y. Sokona, E. Farahani, S. Kadner, K. Seyboth, A. Adler, I. Baum, S. Brunner, P. Eickemeier, B. Kriemann, J. Savolainen, S. Schlömer, C. von Stechow, T. Zwickel, and J. C. Minx, editors. Cambridge University Press, Cambridge, UK.

Johnson, M. E., E. Schiffer, V. Oboh, and N. L. Aberman. 2009. Mapping the policy process in Nigeria: examining linkages between research and policy. International Food Policy Research Institute, Washington, D.C., USA. 
Kelly, N., J. M. Bennett, and A. Starasts. 2017. Networked learning for agricultural extension: a framework for analysis and two cases. Journal of Agricultural Education and Extension 23 (5):399-414. https://doi.org/10.1080/1389224X.2017.1331173

Kemp, R., J. Schot, and R. Hoogma. 1998. Regime shifts to sustainability through processes of niche formation: the approach of strategic niche management. Technology Analysis and Strategic Management 10(2):175-198. https://doi.org/10.1080/09537329808524310

Kilelu, C. W., L. Klerkx, C. Leeuwis, and A. Hall. 2011. Beyond knowledge brokerage: an exploratory study of innovation intermediaries in an evolving smallholder agricultural system in Kenya. Knowledge Management for Development Journal 7 (1):84-108. https://doi.org/10.1080/19474199.2011.593859

Klerkx, L., A. Hall, and C. Leeuwis. 2009. Strengthening agricultural innovation capacity: Are innovation brokers the answer? International Journal of Agricultural Resources, Governance and Ecology 8(5/6):409-438. https://doi.org/10.1504/ ijarge.2009.032643

Klerkx, L., and C. Leeuwis. 2008. Matching demand and supply in the agricultural knowledge infrastructure: experiences with innovation intermediaries. Food Policy 33(3):260-276. https://doi. org/10.1016/j.foodpol.2007.10.001

Klerkx, L., L. P. Pant, C. Leeuwis, S. Cummings, E. le Borgne, I. Kulis, L. Lamoureux, and D. Senmartin. 2011. Beyond the conventional boundaries of knowledge management: navigating the emergent pathways of learning and innovation for international development. Knowledge Management for Development Journal 7(1):1-7. https://doi.org/10.1080/19474199.2011 .593880

Koh, S. C. L., and K. H. Tan. 2006. Operational intelligence discovery and knowledge-mapping approach in a supply network with uncertainty. Journal of Manufacturing Technology Management 17(6):687-699. https://doi.org/10.1108/17410380610678747

Liebowitz, J. 2005. Linking social network analysis with the analytic hierarchy process for knowledge mapping in organizations. Journal of Knowledge Management 9(1):76-86. https://doi.org/10.1108/13673270510582974

Losch, B. 2016. Structural transformation to boost youth labour demand in sub-Saharan Africa: the role of agriculture, rural areas and territorial development. Employment and Market Policies. Working Paper No.204. International Labour Organization, Geneva, Switzerland. [online] URL: https://www.ilo.org/wcmsp5/ groups/public/---ed emp/documents/publication/wems 533993.pdf

Markard, J., R. Raven, and B. Truffer. 2012. Sustainability transitions: an emerging field of research and its prospects. Research Policy 41(6):955-967. https://doi.org/10.1016/j. respol.2012.02.013

Markard, J., and B. Truffer. 2008. Technological innovation systems and the multi-level perspective: towards an integrated framework. Research Policy 37(4):596-615. https://doi.org/10.1016/ j.respol.2008.01.004

McMichael, P. 2009. A food regime genealogy. Journal of Peasant Studies 36(1):139-169. https://doi.org/10.1080/03066150902820354
Meadows, D. H., J. Randers, and W. W. Behrens. 1972. The limits to growth: a report to the club of Rome. Universe Books, New York, USA.

Metelerkamp, L. 2014. Consolidation in the food system: risks, opportunities and responsibilities. Ernst and Young, Johannesburg, South Africa.

Metelerkamp, L. 2019. Learning for change: youth and niche environments in food system transitions. Dissertation. Stellenbosch University, Stellenbosch, South Africa.

Minde, I., F. Terblanche, B. Bashaasha, C. Madakadze, J. Snyder, and A. Mugisha. 2015. Challenges for agricultural education and training (AET) institutions in preparing growing student populations for productive careers in the agri-food system. Journal of Agribusiness in Developing and Emerging Economies 5 (2):137-169. https://doi.org/10.1108/JADEE-02-2015-0011

Moore, M. L., D. Riddell, and D. Vocisano. 2015. Scaling out, scaling up, scaling deep: strategies of non-profits in advancing systemic social innovation. Journal of Corporate Citizenship 58 (1):67-84. https://doi.org/10.9774/GLEAF.4700.2015.ju.00009

Moore, M.-L., O. Tjornbo, E. Enfors, C. Knapp, J. Hodbod, J. A. Baggio, A. Norström, P. Olsson, and D. Biggs. 2014. Studying the complexity of change: toward an analytical framework for understanding deliberate social-ecological transformations. Ecology and Society 19(4):54. https://doi.org/10.5751/ES-06966-190454

Moore, M., and F. Westley. 2011. Surmountable chasms: networks and social innovation for resilient systems. Ecology and Society 16(1):5. https://doi.org/10.5751/ES-03812-160105

Moschitz, H., D. Roep, G. Brunori, and T. Tisenkopfs. 2015. Learning and innovation networks for sustainable agriculture: processes of co-evolution, joint reflection and facilitation. Journal of Agricultural Education and Extension 21(1):1-11. https://doi. org/10.1080/1389224X.2014.991111

Naidoo, P. 2012. Roots of disagreement: battle for the soul of the organic farming industry. Financial Mail, 30 October. [online] URL: https://www.bizcommunity.com/Article/196/358/84349.html

National Planning Commission (NPC). 2013. South African national development plan vision 2030. NPC, Pretoria, South Africa.

National Youth Development Agency (NYDA). 2015. National youth policy:2015-2020. NYDA, Pretoria, South Africa.

Nellemann, C., M. MacDevette, T. Manders, B. Eickhout, B. Svihus, A. G. Prins, and B. P. Kaltenborn, editors. 2009. The environmental food crisis: the environment's role in averting future food crises. United Nations Environment Programme, GRIDArendal, Arendal, Norway.

Okunlola, A., M. Ngubane, B. Cousins, and A. du Toit. 2016. Challenging the stereotypes: small-scale black farmers and private sector support programmes in South Africa. Working Paper 53. Institute for Poverty, Land and Agrarian Studies, Cape Town, South Africa.

Patel, R. 2012. Stuffed and starved: the hidden battle for the world food system. Portebello Books, London, UK. 
Ramos-Mejía, M., M. L. Franco-Garcia, and J. M. JaureguiBecker. 2018. Sustainability transitions in the developing world: challenges of socio-technical transformations unfolding in contexts of poverty. Environmental Science and Policy 84:217-223. https://doi.org/10.1016/j.envsci.2017.03.010

Rauschmayer, F., T. Bauler, and N. Schapke. 2015. Towards a thick understanding of sustainability transitions: linking transition management, capabilities and social practices. Ecological Economics 109(1):211-221. https://doi.org/10.1016/j. ecolecon.2014.11.018

Reardon, T., C. P. Timmer, C. B. Barrett, and J. Berdegué. 2003. The rise of supermarkets in Africa, Asia, and Latin America. American Journal of Agricultural Economics 85(5):1140-1146. https://doi.org/10.1111/j.0092-5853.2003.00520.x

Regional Network of Agricultural Policy Research Institutes (ReNAPRI). 2014. Anticipating Africa's policy challenges in the decade ahead. Feed the Future Innovation Lab for Food Security Policy, Policy Research Brief 4. Feed the Future, U.S. Aid, Michigan State University, International Food Policy Research Institute, and University of Pretoria, Pretoria, South Africa.

Rockström, J., W. Steffen, K. Noone, Å. Persson, F. S. Chapin III, E. F. Lambin, T. M. Lenton, M. Scheffer, C. Folke, H. J. Schellnhuber, et al. 2009. A safe operating space for humanity. Nature 461:472-475. https://doi.org/10.1038/461472a

Schiffer, E., and J. Hauck. 2010. Net-Map: collecting social network data and facilitating network learning through participatory influence network mapping. Field Methods 22 (3):231-249. https://doi.org/10.1177/1525822X10374798

Schiffer, E., and D. Waale. 2008. Tracing power and influence in networks. International Food Policy Research Institute, Washington, D.C., USA.

Sharpe, B., A. Hodgson, G. Leicester, A. Lyon, and I. Fazey. 2016. Three horizons: a pathways practice for transformation. Ecology and Society 21(2):47. https://doi.org/10.5751/ES-08388-210247

Shove, E., and G. Walker. 2007. CAUTION! Transitions ahead: politics, practice, and sustainable transition management. Environment and Planning A: Economy and Space 39(4):763-770. https://doi.org/10.1068/a39310

Smith, A., J.-B. Voss, and J. Grin. 2010. Innovation studies and sustainability transitions: the allure of the multi-level perspective and its challenges. Research Policy 39(4):435-448. https://doi. org/10.1016/j.respol.2010.01.023

Spaull, N. 2013. South Africa's education crisis: the quality of education in South Africa 1994-2011. Centre for Development and Enterprise, Johannesburg, South Africa.

Stuckler, D., and M. Nestle. 2012. Big food, food systems, and global health. PLoS Medicine 9(6):e1001242. https://doi. org/10.1371/journal.pmed.1001242

Swart, R. J., P. Raskin, and J. Robinson. 2004. The problem of the future: sustainability science and scenario analysis. Global Environmental Change 14(2):137-146. https://doi.org/10.1016/j. gloenvcha.2003.10.002
Teddlie, C., and A. Tashakkori. 2009. Foundations of mixed methods research: integrating quantitative and qualitative approaches in the social and behavioral sciences. SAGE, Thousand Oaks, California, USA.

Torre, D. M., C. van der Vleuten, and D. Dolmans. 2016. Theoretical perspectives and applications of group learning in PBL. Medical Teacher 38(2):189-195. https://doi. org/10.3109/0142159X.2015.1009429

Tschirley, D. L., J. Snyder, M. Dolislager, M. Dolislager, T. Reardon, S. Haggblade, J. Goeb, L. Traub, F. Ejobi, and F. Meyer. 2015. Africa's unfolding diet transformation: implications for agrifood system employment. Journal of Agribusiness in Developing and Emerging Economies 5(2):102-136. https://doi. org/10.1108/jadee-01-2015-0003

White, B. 2012. Agriculture and the generation problem: rural youth, employment and the future of farming. IDS Bulletin 43 (6):9-19. https://doi.org/10.1111/j.1759-5436.2012.00375.x

Wiek, A., A. Xiong, K. Brundiers, and S. van der Leeuw. 2014. Integrating problem- and project-based learning into sustainability programs: a case study on the School of Sustainability at Arizona State University. International Journal of Sustainability in Higher Education 15(4):431-449. https://doi. org/10.1108/IJSHE-02-2013-0013

Willer, H., and J. Lernoud. 2015. The world of organic agriculture: statistics and emerging trends 2015. Research Institute of Organic Agriculture (FiBL), Frick, Switzerland, and Organics International (IFOAM), Bonn, Germany.

Willer, H., M. Yussefi-Menzler, and N. Sorensen. 2008. The world of organic agriculture: statistics and emerging trends 2008. Routledge, London, UK. https://doi.org/10.4324/9781849775991

Zechner, M., and B. R. Hansen. 2015. Building power in a crisis of social reproduction. ROAR Magazine 1:132-151.

Zheng, B., M. Niiya, and M. Warschauer. 2015. Wikis and collaborative learning in higher education. Technology, Pedagogy and Education 24(3):357-374. https://doi.org/10.1080/1475939X.2014 .948041 